\title{
Evaluation of productive and reproductive performance of Black Bengal goat
}

\author{
RC Paul', ANMI Rahman², S Debnath ${ }^{1}$, MAMY Khandoker*1
}

${ }^{1}$ Department of Animal Breeding and Genetics, Bangladesh Agricultural University, Mymensigh 2202; ${ }^{2}$ Department of Animal Nutrition, Genetics and Breeding Sher-e-Bangla Agricultural University, Sher-e-Bangla Nagar, Dhaka 1207, Bangladesh

\begin{abstract}
The present study was conducted with a view to know the productive and reproductive parameters of Black Bengal goat in a nucleus breeding flock of Bangladesh Agricultural University, and two other regions i.e., Modhupur (Tangail) and Dimla, (Nilphamari). Data were collected on a regular basis from January 2011 to January 2012. The results showed that birth weight of kids was significantly affected by type of birth $(p<0.01)$, parity of dam $(p<0.01)$ and season of birth $(p<0.05)$ in three different regions. Yearling weight was varied significantly by sex of kid $(p<0.01)$ and season of birth $(p<0.05)$ in three different regions. Daily milk production was significantly affected by type of birth $(p<0.01)$, parity of dam $(p<0.01)$ and season of birth $(p<0.01)$. Litter size and age at first conception were significantly affected by parity of dam. Kid mortality was significantly affected by season of birth $(p<0.01)$ in nucleus flock. The results indicated that sex of kid, type of birth, parity of dam and season of birth influenced the productive and reproductive parameters in nucleus flock, Modhupur and Dimla and the performance also varied between nucleus flock and field levels.
\end{abstract}

Key words: Black Bengal goat, productive traits, reproductive traits

Bangladesh Animal Husbandry Association. All rights reserved. Bang. J. Anim. Sci. 2014.43 (2): 104-111

\section{Introduction}

Black Bengal goat, the only recognized breed of Bangladesh, are being reared primarily for meat production. For that reason body weight specially birth weight and mature body weight could be considered as the most important factor. During selection of goat attention should be given on the age, body weight, mortality rate, kidding, and average weight at maturity etc.

Adult body weight is an important economic factor which influences the growth and production pattern of any goat enterprise and has more influence mainly on the growth behavior of kids (McGregor 1984). Reproductive performance is one of the main factors which determine the productivity of the goat irrespective of their use for meat, milk, skin or hair production (Sivaraj 1991). Birth weight and body weight of goat is considered as important traits because there is a positive correlation between birth weight and growth rate, age at maturity and mature body weight (Banergee 1989), which influence the future productive and reproductive performance of the animal. It is now well documented that selection of good quality bucks and their widespread use could be able to improve birth weight, body weight gain and milk yield. Despite many good characteristics, low birth weight, insufficient milk produced by dam and slow growth rate in Black Bengal goats were identified as the major constraints directly associated with higher kid mortality and hence reducing total biomass production (Husain et al. 1998). However there have sizable genetic variations in different economic traits between individuals in Black Bengal goat within and between locations (Amin et al. 2000). In order to cope with increasing demand of goat products, their production potentialities in terms of meat and milk need to be genetically promoted (Husain et al. 1998)

In spite of promises of Black Bengal goat amongst the world goat genetic resource the systematic information on production parameters in Black Bengal goat is very limited, although a lot of work has been done on various parameters 
of Black Bengal goat including productive and reproductive traits (Amin et al. 2001; Faruque et al. 2010). It is essential to compile the parameters by which Black Bengal goat can be described distinctively from others, which will be helpful for the breeders as well as farmers for the selection of goat. The present study was, therefore, designed to study the productive and reproductive performance of Black Bengal goat in three different regions of Bangladesh.

\section{Materials and Methods}

Data for productive and reproductive traits on individual animal were recorded on a regular basis covering from January 2011 to January 2012. Data on milk production, birth weight, 12 months body weight and body weight at first estrus was taken on 62, 145, 186 does; 61, 57, 55 kids; 57, 71, 55 goats and 73, 53, 125 does from Nucleus Breeding Flock (NBF) of Bangladesh Agricultural University (BAU), Modhupur, Tangail and Dimla, Nilphamari, respectively. Data was also taken on kid mortality, litter size, age at first heat, age at first conception and mortality from 17, 36, 38 kids; 98, 186, 186 kids; 70, 87, 125 does and 69, 87, 125 does from NBF, Modhupur and Dimla, respectively.

Under the activities of Mennonite Central Committee (MCC) does were distributed to the selected farmers in Dimla and Modhupur. Most of the goats were maintained by the poor marginal farmers, they did not have the economic ability to house them separately. Hence, goat was mostly kept in open places during the day time. At night they were mainly kept in the living room of the owner. Only few of the farmers have separate houses for their goat. The house is also not cleaned properly by the farmers. They also use corridor, kitchen, and cowshed for keeping their goat. The farmers did not provide extra care for bedding or feeding. In most of the situations the goat is looked after by the women and children. Grazing was only the means of feeding the animals and they were grazed in the fellow lands, river, canals and road sides and around the bushes and fields. During the critical months especially from late winter to early summer, there was acute shortage of green grasses on the field and farmers did not have any alternative sources of feeding their animals except collecting some tree leaves, household scrapes and kitchen wastes. In the study areas prevention and treatment facilities were seriously lacking. Due to financial constraints farmers were usually not able to practice vaccination and medication.

In the NBF, the goats were fed with Napier and/or German grass twice daily as per requirement. The feed was supplemented with commercial concentrate (crude protein content$120 \mathrm{gm} / \mathrm{kg}$ DM and energy content- $10.4 \mathrm{MJ}$ $\mathrm{ME} / \mathrm{kg} \mathrm{DM}$ ) in the morning and afternoon at the rate of $100 \mathrm{gm} /$ goat. Clean and safe water was made available at all times. Throughout this study the nutrition of goats remained uniform. The flock was maintained under semi-intensive system. The house was provided with necessary arrangement for feeding and watering with provision of sufficient access to fresh air and their movement freely. All goats were vaccinated against PestedesPetits Ruminants (PPR). Regular deworming at 3-6 months interval according to fecal examination for parasites was done. Regular dipping was also performed on every month

In the present study, birth weight, body weight at twelve months, body weight and age at first estrus, milk yield, litter size, age at first conception, and kid mortality in three different regions were considered.

Simple ANOVA was performed using statistical package for Social Science 11.5 (SPSS Inc. 2000) for data analyses considering sex of kid, type of birth, parity of dam, season of birth as class variable. To see the significant differences among mean values, DMRT was performed.

\section{Results and Discussion}

Table 1 shows the birth weights of kids with the different effects as sex of kid, type of birth, parity of dam and season of birth in three different regions of Bangladesh. Average birth weight of kid in NBF, Modhupur and Dimla were $1.09 \pm 0.27,1.09 \pm 0.25$, and $1.10 \pm 0.27 \mathrm{~kg}$, respectively, which are in agreement with the findings by Kanaujia and Pander (1988) who reported that birth weight of Black Bengal kid was $1.13 \mathrm{~kg}$. Paul (2008) studied on a total of 47 Black Bengal does and found that birth weight of kid was $1.01 \pm 0.23 \mathrm{~kg}$. The highest birth weight was found in Nilphamari $(1.10 \pm 0.27 \mathrm{~kg})$ in the present study. The birth weight of kid was not 


\section{Productive and reproductive traits of Black Bengal goat}

significantly influenced by sex of kid at three different regions which agrees with the findings of Singh (1998) in Black Bengal kids. Birth weight of kids was significantly affected by type of birth $(p<0.01)$ at three different regions. Among the different types of birth, single kids showed the highest weight at birth followed by twins and triplets which is similar as obtained by Husain et al. (1996). Parity of dam significantly $(p<0.01)$ influenced the birth weight in three different regions. There was a tendency to increase weight with the advance of parity in all regions. Significantly highest birth weight was observed in $3^{\text {rd }}$ parity and lowest in $1^{\text {st }}$ parity in all regions. A similar result was obtained by Husain et al. (1996) who reported that among the four parities, kid's birth weight was lower in $1^{\text {st }}$ parity does compared to $2^{\text {nd }}, 3^{\text {rd }}$ and $4^{\text {th }}$ parity. Season of birth has a significant $(p<0.05)$ effect on birth weight. Winter born kids were significantly $(p<0.05)$ heavier than that of other seasons at three different regions. Warmington and Kirton (1990) reported that kid live weight was influenced by season of birth in several breeds and it plays an important role in growth performance indirectly through its influence on the dams nutrition and hence quantity of milk available to the un-weaned kids.

Table 1. Effect of different factors on birth weight of kids $(\mathrm{kg})$ in three regions

\begin{tabular}{|c|c|c|c|}
\hline Factors & NBF & Modhupur & Dimla \\
\hline Sex of kid & $\overline{N S}$ & $\overline{\mathrm{NS}}$ & NS \\
\hline Male & $1.10 \pm 0.07(56)$ & $1.07 \pm 0.02(96)$ & $1.08 \pm 0.07(29)$ \\
\hline Female & $1.08 \pm .0 .07(66)$ & $1.03 \pm 0.03(69)$ & $1.00 \pm 0.03(28)$ \\
\hline Type of birth & *k & ** & ** \\
\hline Single & $1.11 \mathrm{a} \pm 0.06(42)$ & $1.21 \mathrm{a} \pm 0.04(35)$ & $1.23^{a} \pm 0.07(28)$ \\
\hline Twin & $1.09 a \pm 0.05(56)$ & $1.15^{b} \pm 0.02(104)$ & $1.17^{b} \pm 0.05(27)$ \\
\hline Triplet & $0.77^{b} \pm 0.14(24)$ & $0.78 c \pm 0.04(26)$ & $0.77 \pm 0.11(2)$ \\
\hline Parity of dam & $\star \star$ & * & *夫 \\
\hline $1 s t$ & $0.99 \mathrm{~b} \pm 0.05(56)$ & $1.07 \mathrm{~b} \pm 0.03(49)$ & $0.83^{b} \pm 0.03(36)$ \\
\hline $2^{\text {nd }}$ & $1.15^{a b} \pm 0.06(42)$ & $1.09 a b \pm 0.03(94)$ & $0.98^{a b} \pm 0.03(14)$ \\
\hline $3^{\text {rd }}$ & $1.25 \mathrm{a} \pm 0.06(24)$ & $1.16^{a} \pm 0.05(22)$ & $1.12^{\mathrm{a}} \pm 0.05(7)$ \\
\hline Birth season & * & * & * \\
\hline Winter & $1.20 \mathrm{a} \pm 0.07(42)$ & $1.10^{\mathrm{a}} \pm 0.03(55)$ & $1.12^{\mathrm{a} \pm 0.03(13)}$ \\
\hline Summer & $1.07^{a b} \pm 0.06(67)$ & $1.03^{a b} \pm 0.02(93)$ & $1.05^{\mathrm{ab}} \pm 0.02(36)$ \\
\hline Rainy & $0.94 \mathrm{~b} \pm 0.09$ (13) & $0.93^{b} \pm .05(17)$ & $0.95^{\mathrm{b}} \pm 0.05$ (8) \\
\hline Mean & $1.09 \pm 0.27$ & $1.09 \pm 0.25$ & $1.10 \pm 0.27$ \\
\hline
\end{tabular}

$N B F$, nucleus breeding flock; values in the parentheses indicate the number of observation; means with different superscripts within each column and trait differed significantly; NS, non-significant; *, $(p<0.05)$; **, $(p<0.01)$
Effect of different factors (sex of kid, type of birth, parity of dam and season of birth) on body weight at 12 months of goat at three different regions of Bangladesh are presented in Table 2 . The mean body weight at 12 months age for Black Bengal goats of NBF, Modhupur and Dimla were $14.40 \pm 0.53,14.20 \pm 0.63$ and $14.30 \pm 0.66$ $\mathrm{kg}$, respectively. A similar result was found by Husain (1999) who reported that the body weight of goat at 12 month of age was $15.25 \mathrm{~kg}$ in Black Bengal goats. The body weight at 12 months varied $(p<0.01)$ according to sex. The result is in agreement with Hasnath et al. (2003) who reported that the body weight of male and female Black Bengal goats at 12 months was 13.19 and $12.47 \mathrm{~kg}$, respectively and male goats obtained significantly $(p<0.01)$ higher live weight than female. The effect of type of birth and parity of dam were insignificant on the body weight at 12 months in all regions. Variation in body weight due to season was significant $(p<0.05)$ in all regions. The result is in agreement with Mia (2011). In winter, body weight was higher in Modhupur and Dimla and lower in NBF. Variation in body weight may be due to availability of feeds and fodder and other management.

Table 2. Effect of different factors on 12-month body weight $(\mathrm{kg})$ of goat in three regions

\begin{tabular}{lccc}
\hline Factors & NBF & Modhupur & Dimla \\
\hline Sex of kid & ${ }^{*}$ & ${ }^{*}$ & ${ }^{*}$ \\
\hline Male & $14.69^{a} \pm 0.93(35)$ & $14.40^{a} \pm 0.93(30)$ & $14.43^{\mathrm{a}} \pm 0.81(29)$ \\
Female & $10.02^{\mathrm{b}} \pm 0.96(36)$ & $9.30^{\mathrm{b}} \pm 0.90(27)$ & $9.42^{\mathrm{b}} \pm 0.78(26)$ \\
\hline Birth type & $\mathrm{NS}$ & $\mathrm{NS}$ & $\mathrm{NS}$ \\
Single & $13.20 \pm 0.84(30)$ & $13.31 \pm 0.87(25)$ & $13.25 \pm 0.88(20)$ \\
Twins & $12.56 \pm 0.69(39)$ & $12.71 \pm 0.71(29)$ & $12.65 \pm 0.72(29)$ \\
Triplets & $11.31 \pm 1.92(2)$ & $9.80 \pm 1.82(3)$ & $9.87 \pm 1.64(6)$ \\
\hline Parity of dam & $\mathrm{NS}$ & $\mathrm{NS}$ & $\mathrm{NS}$ \\
1st & $12.46 \pm 0.88(36)$ & $11.86 \pm 0.85(35)$ & $11.93 \pm 0.67(34)$ \\
2nd & $12.47 \pm 0.99(25)$ & $12.38 \pm 1.07(16)$ & $12.40 \pm 0.88(16)$ \\
3rd & $12.13 \pm 1.21(10)$ & $11.30 \pm 1.20(6)$ & $11.45 \pm 1.25(5)$ \\
\hline Birth season & $*$ & ${ }^{*}$ & $*$ \\
Winter & $13.12^{\mathrm{b}} \pm 0.75(22)$ & $13.75^{\mathrm{a}} \pm 0.77(16)$ & $13.83^{\mathrm{a}} \pm 0.66(15)$ \\
Summer & $13.93^{\mathrm{a}} \pm 0.74(47)$ & $12.30^{\mathrm{b}} \pm 0.70(39)$ & $12.40^{\mathrm{a}} \pm 0.53(38)$ \\
Rainy & $10.00^{\mathrm{c}} \pm 1.96(2)$ & $9.50^{c} \pm 1.89(2)$ & $9.59^{\mathrm{b}} \pm 1.83(2)$ \\
\hline Mean & $14.40 \pm 0.53$ & $14.20 \pm 0.63$ & $14.30 \pm 0.66$ \\
\hline
\end{tabular}

$N B F$, nucleus breeding flock; values in the parentheses indicate the number of observation; means with different superscripts within each column and trait differed significantly; NS, non-significant; *, $(p<0.05)$; **, $(p<0.01)$ 
Effects of different factors (parity of dam, season of birth) on body weight at first estrus of goat in three different regions of Bangladesh are shown in Table 3. Average body weight at first estrus of does in NBF, Modhupur and Dimla were $9.70 \pm 0.67,9.48 \pm 0.34$ and $9.12 \pm 0.47 \mathrm{~kg}$, respectively. The higher body weight at first estrus was found in NBF $(9.70 \pm 0.67 \mathrm{~kg})$. Faruque et al. (2010) reported that body weight at first estrus in Black Bengal goat was $9.62 \pm 0.76$ and $9.34 \pm 0.62 \mathrm{~kg}$ in intensive and semi-intensive system, respectively which is similar to the present study. Weight at first estrus varies from 9.2 to $18.0 \mathrm{~kg}$ in some small and dwarf breeds of goat (Mukundan 1980) which is also similar to the present findings. Parity of dam has significant $(p<0.01)$ effect on body weight at first estrus in Dimla and also body weight at first estrus was high, which may be due to environmental cause. In $2^{\text {nd }}$ and $3^{\text {rd }}$ parity body weight at first estrus tends to decrease gradually which is almost similar to the result of Amin (2000) who found that weight of Black Bengal goat was $10.81 \mathrm{~kg}$ in $1^{\text {st }}$ and $9.73 \mathrm{~kg}$ in $2^{\text {nd }}$ generation, respectively. Effect of season of birth on body weight at first estrus was insignificant at three different regions. The result is in agreement with Amin (2000) who did not find any effect of season on body weight at first estrus of goat.

Table 3. Effect of different factors on body weight $(\mathrm{kg})$ at first estrus of goat in three regions

\begin{tabular}{|c|c|c|c|}
\hline Factors & NBF & Modhupur & Dimla \\
\hline Parity of dam & NS & NS & *夫 \\
\hline $1 \mathrm{st}$ & $10.07 \pm 0.55(27)$ & $10.34 \pm .19(37)$ & $10.37 a \pm 0.24(91)$ \\
\hline 2nd & $9.51 \pm 0.48(35)$ & $8.85 \pm 0.18(42)$ & $8.67^{b} \pm 0.43(23)$ \\
\hline 3 rd & $9.97 \pm 0.85(11)$ & $8.16 \pm 0.40(8)$ & $8.48^{b} \pm .59(11)$ \\
\hline Season of birth & NS & NS & NS \\
\hline Winter & $9.33 \pm 0.55(23)$ & $9.21 \pm 0.23(28)$ & $9.82 \pm 0.34(44)$ \\
\hline Summer & $9.87 \pm 0.45(41)$ & $9.24 \pm 0.20(44)$ & $10.68 \pm 0.29(68)$ \\
\hline Rainy & $10.34 \pm 0.93(9)$ & $8.90 \pm 0.30(16)$ & $9.58 \pm 0.55(13)$ \\
\hline Mean & $9.70 \pm 0.67$ & $9.48 \pm 0.34$ & $9.12 \pm 0.47$ \\
\hline
\end{tabular}

$N B F$, nucleus breeding flock; Values in the parentheses indicate the number of observation; Means with different superscripts within each column and trait differed significantly; NS, non-significant; *, $(p<0.05)$; **, $(p<0.01)$

Effects of different factors (parity of dam, season of birth) on age at first estrus of does at three different regions of Bangladesh are shown in Table 4. The mean age at first estrus for Black
Bengal does of NBF, Modhupur and Dimla were found to be $8.79 \pm 0.34,9.24 \pm 0.33$ and $8.63 \pm 0.30$ months, respectively The higher age at first estrus was found in Modhupur (9.24 \pm 0.33 months). Miah and Alim (2009) reported that in Black Bengal goat, age of maturity in intensive and semi-intensive system were $202.5 \pm 7.1$ and $237.5 \pm 5.5$ days, respectively which are close to the findings of present study. This study strongly support the findings of Akhter et al.(2006) who reported that age at first estrus in Black Bengal goat was $281.02 \pm 9.93$ days. Parity of dam has significant $(p<0.01)$ effect on age at first estrus in Dimla. The result of this study partially support the result of Amin et al. (2000), who studied three genetic groups of Black Bengal does that were crossbred Jamnapari $x$ Black Bengal, selected Black Bengal and random bred Black Bengal. They found that their respective age to first estrus were 319, 250, 241 and 362, 242, 259 days in first and second generation. Small and dwarf Indian breeds attain puberty as early as 150 days with better management and care of female kids (Husain 1995).

Table 4. Effect of different factors on age at first estrus (month) of does in three regions

\begin{tabular}{lccc}
\hline Factors & NBF & Modhupur & Dimla \\
\hline Parity of dam & NS & NS & ${ }^{\star \star}$ \\
$1^{\text {st }}$ & $9.76 \pm 0.25(43)$ & $9.76 \pm 0.25(37)$ & $10.93^{\mathrm{a}} \pm 0.24(91)$ \\
$2^{\text {nd }}$ & $9.18 \pm 0.24(19)$ & $9.18 \pm 0.24(42)$ & $8.677^{\mathrm{b}} \pm 0.43(23)$ \\
$3^{\text {rd }}$ & $8.77 \pm 0.52(8)$ & $8.77 \pm 0.52(8)$ & $8.60^{\mathrm{b} \pm .59(11)}$ \\
\hline Season of birth & $\mathrm{NS}$ & $\mathrm{NS}$ & $\mathrm{NS}$ \\
Winter & $9.37 \pm 0.30(17)$ & $9.37 \pm 0.30(29)$ & $9.82 \pm 0.34(44)$ \\
Summer & $8.71 \pm 0.26(41)$ & $8.71 \pm 0.26(43)$ & $10.68 \pm 0.29(68)$ \\
Rainy & $9.63 \pm 0.39(12)$ & $9.63 \pm 0.39(15)$ & $9.58 \pm 0.55(13)$ \\
\hline Mean & $8.79 \pm 0.34$ & $9.24 \pm 0.33$ & $9.63 \pm 0.30$ \\
\hline
\end{tabular}

NBF, nucleus breeding flock; values in the parentheses indicate the number of observation; means with different superscripts within each column and trait differed significantly; NS, non-significant; *, $(p<0.05)$; **, $(p<0.01)$

The daily milk production of Black Bengal does from three regions with the different effects is given in Table 5 . Average daily milk production of Black Bengal does in NBF, Modhupur and Dimla were $387.01 \pm 26.71,217.32 \pm 29.51$ and $218.42 \pm$ $28.31 \mathrm{ml}$, respectively. The higher milk production was found in NBF (387.01 $26.71 \mathrm{ml})$. Mia (2011) reported that milk yield of Black Bengal does in NBF is $354.76 \mathrm{ml}$ which is close to the present study. Type of birth has significant $(p<0.01)$ 


\section{Productive and reproductive traits of Black Bengal goat}

effect on daily milk production in all regions. The milk yield of goat was significantly affected by various factors such as breed, age of goat at kidding, season of kidding and parity of the dam (Prakash et al. 1971). Single kidded dams were inferior in milk yield compared to twin kidded dams. Similar results were found in Zaraibi goats in Egypt (Hamed et al. 2009). Mourad (1992) observed that litter size affected milk yield of goats until weaning. Parity of dam has significant $(p<0.01)$ effect on milk yield in all regions. Milk yield increased gradually with the progress of parity in the present study. Highest milk yield was obtained in third lactation whereas lowest in first lactation. The results of this study were in accordance with the findings in other studies made in the tropics (Hossain et al. 2004). Husain (1995) reported that the milk yield at first parity in Black Bengal goats was $211.3 \mathrm{ml} /$ day which is similar to the present findings in Dimla and Modhupur. Jahangir (2003) reported that daily milk yield in $1^{\text {st }}, 2^{\text {nd }}$ and $3^{\text {rd }}$ parity of Black Bengal goat was 227 to 330,250 to 357 and 297 to 457 $\mathrm{ml}$ day, respectively which is similar to the present study. Hasanat et al. (2003) reported that the milk yield of Black Bengal goats was 200-300 ml/day in first parity.

Table 5. Effect of different factors on daily milk production $(\mathrm{ml})$ of goat in three regions

\begin{tabular}{|c|c|c|c|}
\hline Factors & NBF & Modhupur & Dimla \\
\hline Type of birth & ** & *夫 & ** \\
\hline Single & $303.4^{b} \pm 34.7(30)$ & $291.0^{b} \pm 28.1(73)$ & $290.1^{b} \pm 30.9(99)$ \\
\hline Twin & $457.4^{a} \pm 38.4(32)$ & $358.1^{\mathrm{a}} \pm 12.0(72)$ & $360.0 \mathrm{a} \pm 22.3(87)$ \\
\hline Parity of dam & ** & ** & *k \\
\hline $1^{\text {st }}$ & $305.2^{c} \pm 30.9(25)$ & $182.7^{c} \pm 28.3(60)$ & $184.8^{c} \pm 30.5(92)$ \\
\hline $2^{\text {nd }}$ & $395.9^{b} \pm 38.5(26)$ & $229.8^{b} \pm 32.2(62)$ & $227.8^{b} \pm 42.3(82)$ \\
\hline $3^{\text {rd }}$ & $\begin{array}{c}480.0 \mathrm{a} \pm 52.02 \\
(11)\end{array}$ & $\begin{array}{c}243.24 \mathrm{a} \pm 11.20 \\
(23)\end{array}$ & $\begin{array}{c}241.14 \mathrm{a} \pm 19.10 \\
(12)\end{array}$ \\
\hline Birth season & *夫 & *夫 & ** \\
\hline Winter & $406.6^{b} \pm 32.3(30)$ & $180.4^{b} \pm 33.2(62)$ & $181.4^{b} \pm 35.5(69)$ \\
\hline Summer & $326.6 c \pm 26.9(22)$ & $234.0^{\mathrm{a}} \pm 24.9(60)$ & $239.0 \mathrm{a} \pm 29.5(77)$ \\
\hline Rainy & $430.0 \mathrm{a} \pm 69.3(10)$ & $229.2^{\mathrm{a}} \pm 22.9(23)$ & $232.2^{\mathrm{a}} \pm 28.9(40)$ \\
\hline Mean & $387.01 \pm 26.71$ & $217.32 \pm 29.51$ & $218.42 \pm 28.31$ \\
\hline
\end{tabular}

NBF, nucleus breeding flock; values in the parentheses indicate the number of observation; means with different superscripts within each column and trait differed significantly; NS, non-significant; *, $(p<0.05)$; **, $(p<0.01)$

Milk yield was significantly $(p<0.01)$ varied according to season of kidding (Table 5). Does kidded in summer was the highest milk yielder and does kidded winter was lowest in Modhupur and Dimla. The present result is in agreement with the findings of Mourad (1992). In NBF highest milk was obtained in rainy season and lowest in summer, which is in agreement with the findings of Mia (2011). The difference in daily milk yield between different seasons of the year reported in this study might be attributed to climatological conditions of different seasons and availability of nutritious fodder and biomass in the farm and grazing fields.

Table 6 shows litter size of does due to the effects of parity of dam, season of birth in three different regions of Bangladesh. Average litter size in Black Bengal does in NBF, Modhupur and Dimla were $1.49 \pm 0.14,1.52 \pm 0.11$ and $1.65 \pm$ 0.03 , respectively. Wilson (1988) reported that the litter size of goats under research station and traditional management conditions were 1.16and 1.57 respectively which is similar to the present study.

Table 6. Effect of different factors on litter size of goat in three regions

\begin{tabular}{|c|c|c|c|}
\hline Factors & NBF & Modhupur & Dimla \\
\hline Parity of dam & ** & * & * \\
\hline $1^{\text {st }}$ & $1.37^{\mathrm{b}} \pm 0.07(50)$ & $1.50^{\mathrm{b}} \pm 0.07(92)$ & $1.54^{b} \pm 0.05(92)$ \\
\hline $2^{\text {nd }}$ & $1.52^{\mathrm{ab}} \pm 0.10(37)$ & $1.47 \mathrm{~b} \pm 0.02(82)$ & $1.49 \mathrm{~b} \pm 0.05(82)$ \\
\hline $3^{\text {rd }}$ & $1.84^{a} \pm 0.14(11)$ & $1.81^{\mathrm{a}} \pm 0.11(12)$ & $1.92^{\mathrm{a}} \pm 0.14(12)$ \\
\hline Birth season & NS & NS & NS \\
\hline Winter & $1.54 \pm 0.10(43)$ & $1.51 \pm 0.02(69)$ & $1.61 \pm 0.07(69)$ \\
\hline Summer & $1.47 \pm 0.08(40)$ & $1.47 \pm 0.08(77)$ & $1.67 \pm 0.07(77)$ \\
\hline Rainy & $1.52 \pm 0.14(16)$ & $1.56 \pm 0.04(40)$ & $1.66 \pm 0.09(40)$ \\
\hline Mean & $1.49 \pm 0.14$ & $1.52 \pm 0.11$ & $1.65 \pm 0.03$ \\
\hline
\end{tabular}

$N B F$, nucleus breeding flock; values in the parentheses indicate the number of observation; means with different superscripts within each column and trait differed significantly; NS, non-significant; *, $(p<0.05)$; **, $(p<0.01)$

Mia (2011) conducted an experiment and found value for litter size of doe to be 1.50 in NBF. Parity of dam has significant $(p<0.05)$ effect on litter size in all regions. Highest litter size was observed in $3^{\text {rd }}$ parity in all regions. The present result is in agreement with the findings of Chowdhury et al. (2002), who reported that litter size was affected by parity, age, genetic and environmental factor. They also reported that litter size increased significantly $(p<0.01)$ as parity progressed. The increase in productivity 
with advance of parity indicates improvement of reproductive traits as does reach maturity.

The effect of different factors (parity of dam, season of birth) on age at first conception of does in three different regions of Bangladesh is shown in Table 7. Average age at first conception in Black Bengal does in NBF, Modhupur and Dimla

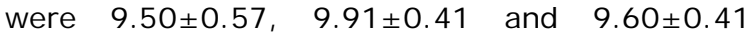
months, respectively. The higher age at first conception was found in Modhupur (9.91 \pm 0.41 months). Prasad and Bhattacharya (1979) reported that average age at first conception of Barbari goat was 344 days which is higher than the present study. On the other hand, Zeshmarani et al. (2007) reported that age at first conception was $229 \pm 4.22$ days, which was less than the present study. Parity of dam has significant $(p<0.01)$ effect on age at first conception in Dimla only. On the contrary, in NBF and Modhupur it was insignificant. This variation may be due to environmental and managemental causes.

Table 7. Effect of different factors on age at first conception (month) of does in three regions

\begin{tabular}{lccc}
\hline Factors & NBF & Modhupur & Dimla \\
\hline Parity of dam & NS & NS & ${ }^{* *}$ \\
$1^{\text {st }}$ & $8.92 \pm 0.40(40)$ & $10.47 \pm 0.34(37)$ & $9.93^{\mathrm{a}} \pm 0.24(91)$ \\
$2^{\text {nd }}$ & $9.46 \pm 0.56(22)$ & $9.86 \pm 0.32(42)$ & $8.677^{\mathrm{b}} \pm 0.43(21)$ \\
$3^{\text {rd. }}$ & $10.31 \pm 0.94(7)$ & $9.40 \pm 0.71(8)$ & $9.48^{\mathrm{a}} \pm 0.59(13)$ \\
\hline Season of birth & NS & NS & ${ }^{*}$ \\
Winter & $9.047 \pm 0.54(20)$ & $10.03 \pm 0.41(28)$ & $9.42^{\mathrm{b}} \pm 0.34(44)$ \\
Summer & $9.11 \pm 0.46(39)$ & $9.63 \pm 0.36(44)$ & $9.68^{\mathrm{a}} \pm 0.29(68)$ \\
Rainy & $10.45 \pm 0.85(10)$ & $10.03 \pm 0.53(15)$ & $9.58^{\mathrm{b}} \pm 0.55(13)$ \\
\hline Mean & $9.50 \pm 0.57$ & $9.91 \pm 0.41$ & $9.60 \pm 0.41$ \\
\hline
\end{tabular}

$N B F$, nucleus breeding flock; values in the parentheses indicate the number of observation; means with different superscripts within each column and trait differed significantly; NS, non-significant; *, $(p<0.05)$; **, $(p<0.01)$

Table 8 shows the effect of season of birth on kid mortality rate at three different regions of Bangladesh. Average kid mortality rate in NBF, Modhupur and Dimla were $10 \pm 0.02,31.03 \pm 0.05$ and $28.78 \pm 0.08 \%$, respectively. Mortality rate was lower in NBF $(10 \pm 0.02 \%)$. Lower kid mortality rate in NBF may be due to good management practices.
Table 8. Effect of different factors on Kid mortality rate in three regions

\begin{tabular}{lccc}
\hline Factor & NBF & Modhupur & Dimla \\
\hline Season & $\star \star$ & NS & NS \\
Winter & $9.00^{\mathrm{b}} \pm 0.02(5)$ & $17.50 \pm 0.90(10)$ & $19.44 \pm .07(9)$ \\
Rainy & $9.09^{\mathrm{b}} \pm 0.06(7)$ & $25.00 \pm 0.06(9)$ & $14.70 \pm .01(10)$ \\
Summer & $13.04^{\mathrm{a}} \pm 0.05(5)$ & $52.77 \pm 0.05(17)$ & $40.62 \pm 0.03(19)$ \\
\hline Mean & $10 \pm 0.02$ & $31.03 \pm 0.05$ & $28.78 \pm 0.08$ \\
\hline
\end{tabular}

$N B F$, nucleus breeding flock; values in the parentheses indicate the number of observation; means with different superscripts within each column and trait differed significantly; NS, non-significant; *, $(p<0.05)$; **, $(p<0.01)$

Mortality rate in NBF in the present study was similar with the finding of Ahmed (2006) who reported that mortality rate of Black Bengal was $10.5 \pm 2.32$. Season of birth has significant $(p<0.01)$ effect on kid mortality rate in NBF. Kid mortality of Black Bengal goat was influenced by weight of doe, parity, birth weight, milk yield, season, feeding, housing and disease and could be as low as $7.0 \%$ if properly managed (Chowdhury et al. 2002). The significantly higher mortality rate was observed in summer $(13.04 \pm 0.05 \%)$ for the period of 0 to 3 months of age and lower in winter season $(9.00 \pm 0.02)$. The effect of season on mortality as observed in this study confirms the results reported by Singh et al. (1991). High mortality of kid on summer may be due to under nutrition and increased susceptibility to diseases. Kid mortality was $17 \%$ in rural scavenging system (Husain 1999) which increased with litter size.

\section{Conclusion}

Results revealed that productive and reproductive performance of Black Bengal goat varied depending of sex, birth type, parity and season. Higher body weight at first estrus and milk yield were found in nucleus breeding flock and higher birth weight, 12-month body weight, litter size, age at first conception, age at first estrus and mortality rate were found in field condition. It is suggested that if proper management can be maintained in field, it will be possible to improve productive and reproductive performance of Black Bengal goat in Bangladesh.

\section{Acknowledgement}

We are gratefully acknowledged United State Department of Agriculture (USDA) for financial support to conduct this research. 


\section{Productive and reproductive traits of Black Bengal goat}

\section{References}

Ahmed HMM (2006). Studies on the performance of Black Bengal goats, Jamunapari goats and their $F_{1}$ crosses at government goat development farm in Savar. MS Thesis, Department of Animal Science, Bangladesh Agricultural University, Mymensingh.

Akhter S, Husain SS, Chowdhury SA, Munzur MM, Dev GK (2006). Estimation of variance components and prediction of breeding value for some economically important traits of Black Bengal goat. Bangladesh Journal of Animal Science, 35: 20-26.

Amin MR, Husain SS, I slam ABMM (2000). Evaluation of Black Bengal goats and their cross with Jamunapari breed for carcass characteristics. Small Ruminant Research, 38: 211-215.

Amin MR, Husain SS, Islam ABMM (2000). Reproductive peculiarities and litter weight in different genetic groups of Black Bengal does. Asian-Australasian Journal of Animal Science, 14: 297-301.

Banergee GC (1989). A Text Book of Animal Husbandry. $7^{\text {th }}$ Edn. Oxford and IBH publishing Co. India.

Chowdhury SA, Bhuiyan MSA, Faruque S (2002). Rearing Black Bengal goat under semiintensive management. 1. Physiological and reproductive performances. AsianAustralasian Journal of Animal Sciences, 15: 477-484.

Faruque S, Chowdhury SA, Siddiquee NU, Afroz MA (2010). Performance and genetic parameters of economically important traits of Black Bengal goat. Journal of Bangladesh Agricutural University, 8: 67-78.

Hamed A, Mabrouk MM, Shaat I, Bata S (2009). Estimation of genetic parameters and some nongenetic factors for litter size at birth and weaning and milk yield traits in Zaraibi goats. Egyptian Journal of Sheep Goat Sciences, 4: 55-64.

Hasanat MT, Husain SS, Amin MR, Miah G (2003). Characterization of Black Bengal goats for some qualitative and quantitative traits. Bangladesh J ournal of Animal Science, 32: 109-120.

Hossain SMJ, Sultana N, Alam MR, Hasnath MR (2004). Reproductive and productive performance of Black Bengal goat under intensive and semi intensive management.
Journal of Biological Sciences, 4: 537-541.

Husain SS, Horst P, I slam ABMM (1995). Effect of different factors on pre-weaning survivability of Black Bengal kids. Small Ruminant Research, 18: 1-5.

Husain SS, Horst P, Islam ABMM (1996). Study on the growth performance of Black Bengal goats in different periods. Small Ruminant Research, 21: 165-171.

Husain SS, Amin MR, Islam ABMM (1998). Goat production and its breeding strategy in Bangladesh. Proc. $1^{\text {st }}$ National Workshop on Animal Breeding held on 26 Nov. 1998, BAU, Mymensingh, Bangladesh. P. 17-36.

Husain SS (1999). Sustainable genetic improvement of economic traits of Black Bengal goats through selective and cross breeding.Bangladesh Agricultural University Research Progress, 10: 72-80.

Jahangir H (2003). Study on milk production practices and potentials for small ruminants in Punjab province. Indian Journal of Animal Sciences, 64: 1242-1247.

Kanaujia S, Pander BL (1988). Heterosis in some economic traits in Beetal and Black Bengal crosses. Indian J ournal of Animal Sciences, 58: 127-129.

McGregor BA (1984). Growth, development and carcass composition of goats. A review, Goat Production and Research in the Tropics. Proceeding of a workshop held at the University of Queensland, Brisbane, Australia, ACAR Proceedings Series No. 7.

Mia MM (2011). Genetic evaluation of performance of Black Bengal goat. PhD Thesis, Department of Animal breeding and genetics, Bangladesh agricultural university, Mymensingh.

Miah G, Alim MA (2009). Performance of Black Bengal goats under intensive and semiintensive farming system. SAARC J ournal of Agriculture, 7: 15-24.

Mourad M (1992). Effects of month of kidding, parity and litter size on milk yield of Alpine goats in Egypt. Small Ruminant Research, 8: $41-46$.

Mukundan G, Khan BU, Bhat PN (1980). Note on growth curve in Malabari goats and their Saanen half breds. Indian Journal of Animal Sciencs, 52: 1112-1114.

Paul S (2008). Characterization of Black Bengal goat. MS Thesis, Department of Animal 
Breeding and Genetics, Bangladesh agricultural university, Mymensingh.

Prakash C, Acharya RM, Dhillon JS (1971). Sources of variation in milk production in Beetal goats. Indian Journal of Animal Sciencs, 41: 356-360.

Prasad SP, Bhattacharyya NK (1979). Oestrus cycle and behavior in different seasons in Barbari nannies. Indian Journal of Animal Sciencs, 49: 1058-1062.

Singh DK, Singh CSP, Mishra HR (1991). Factors affecting growth of Black Bengal and its crossbred with Jamunapari and Beetal goats. Indian Journal of Animal Sciencs, 61: 1101-1105.

Singh NK, Singh DK (1998). Growth rate of Black Bengal and its crosses with Beetal under village conditions. Indian Journal of Animal Sciencs, 68: 988-990.

Sivaraj S (1991). Reproduction techniques In: Goat Husbandry and Breeding in the Tropics. Papers presented in an international seminar carried out by German Foundation for International Development (DSE) at the Institute for Advanced Studies, University of Malaya, Kuala Lumpur.

SPSS, Windows for Version 11.5. (2000). (Microsoft corporation). Trends SPSS Inc. Michigan Avenue, Chicago, IL.19-182

Warmington BG, Kirton AH (1990). Genetic and non-genetic influences of growth and carcass traits of goats. Small Ruminant Research, 3: 147-165.

Wilson RT (1988). Reproductive performance of African indigenous small ruminants under research station and traditional management. In: Proceedings of the $6^{\text {th }}$ World Conference on Animal Production. World Association of Animal production. Helsinki, Finland. P. 585.

Zeshmarani S, Dhara KC, Samanta AK, Samanta R, Majumder SC (2007). Reproductive performance of goats in Eastern and Northeastern India. Livestock Research Rural Development, 19: 114. 